\title{
THE NEW BRAHMANS
}





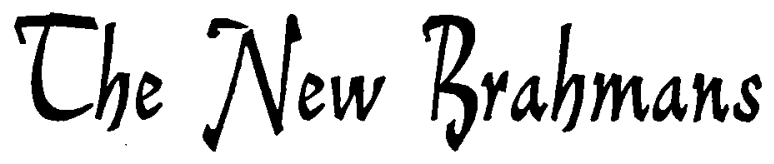

FIVE MAHARASHTRIAN FAMILIES

Selected and Translated by

D. D. KARVE

with the editorial assistance of

Ellen E. McDonald

UNIVERSITY OF CALIFORNIA PRESS

Berkeley and Los Angeles, 1963 
University of California Press

Berkeley and Los Angeles, California

Cambridge University Press

London, England

(C) 1963 by The Regents of the University of California Library of Congress Catalog Card Number 63-I I 389

Printed in the United States of America 